\title{
Base Composition of Deoxyribonucleic Acid from Bovine T-Mycoplasmas
}

\author{
C. J. HOWARD R. N. GOURLAY, D. J. GARWES, D. H. POCOCK, \\ and JACQUELINE COLLINS \\ Agricultural Research Council, Institute for Research on \\ Animal Diseases, Newbury, Berkshire, England
}

\begin{abstract}
The guanine plus cytosine $(\mathrm{G}+\mathrm{C})$ content of the deoxyribonucleic acid from five bovine $\mathrm{T}$-mycoplasmas measured by $\mathrm{CsC} 1$ gradient centrifugation varied from 29 to $29.8 \mathrm{~mol} \%$. The difference in $\mathrm{G}+\mathrm{C}$ content found between the human and bovine strains examined suggest that they represent two different species or subspecies.
\end{abstract}

T-mycoplasmas were first isolated from man by Shepard (11) and subsequently from cattle (15), dogs and monkeys (16), cats (14), and goats (5). This group of microorganisms is united biochemically by its possession of urease and requirement for urea for best growth (4, 12).

Isolates from different animal species have been found to be serologically distinct, but so have certain isolates from the same animal species $(2,7,16)$. Certain differences have been observed between isolates from different animal species; these include their ability to attach to cells, colony size, and susceptibility to a factor in normal rabbit serum that inhibits metabolism $(6,8)$. However, these differences have not been considered sufficient to indicate the existence of different species of T-mycoplasmas.

The purpose of this study was to determine the guanine plus cytosine $(\mathrm{G}+\mathrm{C})$ content of the deoxyribonucleic acid (DNA) from several bovine $\mathrm{T}$-mycoplasmas and to compare the $\mathrm{G}+\mathrm{C}$ contents of bovine and human isolates, human isolates having been previously shown to have $\mathrm{G}+\mathrm{C}$ contents ranging from 26.9 to $28.0 \mathrm{~mol} \%$ (3). A comparison of $\mathrm{G}+\mathrm{C}$ contents of human and bovine isolates might indicate that the two groups of strains represent distinct populations and hence comprise different species.

The two human strains and the five bovine strains listed in Table 1 have been described previously $(2,3,7)$. All strains were grown in 5 -liter volumes of $\mathrm{U} 2$ broth (6). The organisms were harvested by centrifugation at $15,000 \times g$, washed once, and resuspended in $1 \times \operatorname{SSC}(0.15$ $\mathrm{M} \mathrm{NaCl}+0.015 \mathrm{M}$ sodium citrate, $\mathrm{pH} 7$ ). The DNA was extracted by the method of Marmur (9) as modified by Bak and Black (1).
The $\mathrm{G}+\mathrm{C}$ content of the DNA was determined by estimating the buoyant density after equilibrium centrifugation in cesium chloride (10). Escherichia coli strain B DNA (Sigma, London) was used as a reference (density, $\left.1.710 \mathrm{~g} / \mathrm{cm}^{3}[3,10]\right)$.

The $\mathrm{G}+\mathrm{C}$ contents of the DNA samples examined are given in Table 1. The values for the human strains T960 and 58 were 27.4 and $27.5 \mathrm{~mol} \%$, respectively. This compares with the values of 27.1 and $28.0 \mathrm{~mol} \%$ reported by Black et al. (3) and is within the range of 26.9 to $28.0 \mathrm{~mol} \% \mathrm{G}+\mathrm{C}$ content they found for for human T-mycoplasmas. These two human strains were included as controls to ensure that our results could be compared with those previously reported for the human strains (3).

The $\mathrm{G}+\mathrm{C}$ content range found for the bovine strains was 29.0 to $29.8 \%$. Strains A417 and Gri383 cross-react serologically (7) and have identical $\mathrm{G}+\mathrm{C}$ values of $29.0 \mathrm{~mol} \%$. The other three strains are serologically distinct from each other and from strains A417 and Gri383.

The mean $\mathrm{G}+\mathrm{C}$ content of the human isolates, calculated from the results of Black et al. (3), was $27.4 \mathrm{~mol} \%$. That of the bovine strains was $29.3 \%$. Thus the difference in the mean mol\% $\mathrm{G}+\mathrm{C}$ content was 1.9 . The range of $\mathrm{G}+\mathrm{C}$ contents for the human $\mathrm{T}$-mycoplasmas examined by Black et al. (3) was $1.1 \%$, and the range for the bovine strains examined here was $0.8 \%$. The difference between the highest $\mathrm{G}+\mathrm{C}$ content found for a human strain and the lowest $\mathrm{G}+\mathrm{C}$ content found for a bovine strain was $1 \%$.

The range of $\mathrm{G}+\mathrm{C}$ contents of the human and bovine strains is small and the difference between the two groups of isolates is as great as the range of values for strains from either 
TABLE 1. G+C content of DNA from five bovine and two human strains of T-mycoplasmas

\begin{tabular}{|c|c|c|}
\hline \multirow[b]{2}{*}{ Strain } & \multicolumn{2}{|c|}{$\mathrm{G}+\mathrm{C}$ content $(\%)$} \\
\hline & Values & Mean \\
\hline A417 (bovine) & $\begin{array}{l}29.69 \\
28.98 \\
28.27\end{array}$ & 29.0 \\
\hline Gri383 (bovine) & $\begin{array}{l}28.98 \\
29.08\end{array}$ & 29.0 \\
\hline Bu2 (bovine) & $\begin{array}{l}28.68 \\
29.64 \\
28.68\end{array}$ & 29.0 \\
\hline D48 (bovine) & $\begin{array}{l}29.71 \\
29.49\end{array}$ & 29.6 \\
\hline O13 (bovine) & $\begin{array}{l}29.57 \\
29.71 \\
30.05\end{array}$ & 29.8 \\
\hline T960 (human) & $\begin{array}{l}27.76 \\
26.63 \\
27.76\end{array}$ & 27.4 \\
\hline 58 (human) & $\begin{array}{l}27.51 \\
27.49\end{array}$ & 27.5 \\
\hline
\end{tabular}

source. Furthermore, the range of $\mathrm{mol} \% \mathrm{G}+\mathrm{C}$ values observed for mycoplasmas is smaller than that of bacteria (13). These findings indicate that the human and bovine strains represent two distinct populations of microorganisms and support the hypothesis that the T-mycoplasmas examined constitute two different species or subspecies.

\section{LITERATURE CITED}

1. Bak, A. L., and F. T. Black. 1968. DNA base composition of human T-strain mycoplasmas. Nature (London) 219:1044-1045.

2. Black, F. T. 1971. Serological methods for classification of human T-mycoplasmas. 5th Int. Congr. Infect. Dis. 1:407-411.

3. Black, F. T., C. Christiansen, and G. Askaa. 1972. Genome size and base composition of deoxy. ribonucleic acid from eight human T-mycoplasmas. Int. J. Syst. Bacteriol. 22:241-242.
4. Ford, D. K., and J. MacDonald. 1967. Influence of urea on the growth of T-strain mycoplasmas. J. Bacteriol. 93:1509-1512.

5. Gourlay, R. N, J Brownlie, and C. J. Howard. 1973. Isolation of T-my coplasmas from goats, and the production of sub-clinical mastitis in goats by the intramammary inoculation of human T-mycoplasmas. J. Gen. Microbiol. 76:251-254.

6. Howard, C. J., and R. N. Gourlay. 1973. Inhibition by normal rabbit sera of the growth of T-mycoplasma strains isolated from different animal species. J. Gen. Microbiol. 78:277-285.

7. Howard, C. J., and R. N. Gourlay. 1973. Serological comparison of bovine T-mycoplasmas. J. Gen. Microbiol. 79:129-134.

8. Manchee, R. J., and D. Taylor-Robinson. 1969. Enhanced growth of T-strain mycoplasmas with $N$-2-hydroxyethyl piperazine- $N^{\prime}$-2-ethanesulfonic acid buffer. J. Bacteriol. 100:78-85.

9. Marmur, J. 1961. A procedure for the isolation of deoxyribonucleic acid from micro-organisms. J. Mol. Biol. 3:208-218.

10. Schildkraut, C. L.. J. Marmur, and P. Doty. 1962. Determination of the base composition of deoxyribonucleic acid from its buoyant density in $\mathrm{CsCl}$. J. Mol. Biol. 4:430-443.

11. Shepard, M. C. 1954. The recovery of pleuropneumonia-like organisms from negro men with and without non-gonococcal urethritis. Amer. J. Sy ph. Gonor. Vener. Dis. 38:113-124.

12. Shepard, M. C., and C. D. Lunceford. 1967. Occurrence of urease in T-strains of mycoplasma. J. Bacteriol. 93:1513-1520.

13. Somerson, N L., and S. M. Weissmann. 1969. Application of nucleic acid techniques to the study of mycoplasmas and L-phase organisms, $\mathrm{p}$. 201-218. In L. Hayflick (ed.), The mycoplasmatales and the L-phase of bacteria. AppletonCentury-Crofts, New York.

14. Tan, R. J. S., and J. G. Markham. 1971. Feline T-strain mycoplasmas Jap. J. Exp. Med. 41:247248.

15. Taylor-Robinson, D., C. Martin-Bourgon, $T$. Watanabe, and J. P Addey. 1971. Isolation of T-mycoplasmas from dogs and squirrel monkeys: biological and serological comparison with those isolated from man and cattle. J. Gen. Microbiol. 68:97-107.

16. Taylor-Robinson, D., M. H. Williams, and D. A. Haig. 1968. The isolation and comparative biological and physical characteristics of T-mycoplasmas of cattle. J. Gen. Microbiol. 54:33-46. 